S O W I N I E C

R. 29: 2018 , nr 52, s. $139-156$

https://doi.org/10.12797/Sowiniec.29.2018.52.08

\title{
OD Mostycza \\ PO RzECZPOSPOLITĄ MościskĄ
}

CZ. 1:

ZARYS BURZLIWYCH DZIEJÓW MIASTA MOŚCISKA DO ROKU 1916

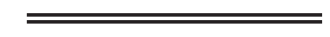

Krzysztof Z. Nowakowski

Historia miasta Mościska związanego z dynastią Jagiellonów i Królestwem Polskim sięga początków XV w. i jest w obecnej historiografii niemal zapomniana. Umykają historykom czasy przedlokacyjne dotyczące dynastii książąt Rurykowiczów oraz Rusi Kijowskiej. Ustawiczne najazdy i wojny doprowadziły do zniszczenia dokumentów lokacyjnych, parafialnych oraz bogatych mościskich księgozbiorów.

Obecnie główne źródła o mieście znajdują się w przewodnikach krajoznawczo-przyrodniczych, np. autorstwa Mieczysława Orłowicza ${ }^{1}$, oraz w postaci hasła w siódmym tomie Słownika geograficznego Królestwa Polskiego i innych krajów słowiańskich ${ }^{2}$. Władysław Łoziński odnotował wiele wydarzeń historycznych w pracy pt. Prawem i lewem - obyczaje na Rusi Czerwonej w I połowie XVII wieku³. O wydarzeniach związanych z okupacją rosyjską w latach 1914-1915 pisał z kolei

1 M. Orłowicz, Ilustrowany przewodnik po Galicji, Bukowinie, Spiszu, Orawie i Śląsku Cieszyńskim, Lwów 1919, s. 257.

2 L. Dziedzicki, Mościska, [w:] Słownik geograficzny Królestwa Polskiego i innych krajów słowiańskich, red. B. Chleb owski et al., t. 6, Warszawa 1885, s. 693-701.

3 W. Łoziński, Prawem i lewem - obyczaje na Rusi Czerwonej w pierwszej połowie XVII wieku, t. 2: Wojny prywatne, Lwów 1931. 
o. Marian Pirożyński w książce o Bernardzie Łubieńskim4. Obszerna relacja z lat 1939-1945 dotycząca klasztoru oo. Redemptorystów znalazła się w tomie Zakony wydanym pod redakcją Jana Drausa i Jana Musiała ${ }^{5}$. W roku 2004 Krzysztof Nowakowski, z okazji sześćsetlecia Mościsk, opublikował artykuł Miasto Mościska dzieje od nadania praw miejskich do wkroczenia Armii Czerwonej $j^{6}$ zamieszczony w roczniku Regionalnego Ośrodka Kultury Edukacji i Nauki w Przemyślu.

O czasach wojny polsko-ukraińskiej, kiedy kluczową rolę odegrały Lwów, Przemyśl, Mościska i Radymno, pisał m.in. Maciej Kozłowski . Tematy związane z konspiracją ZWZ-AK na Zachód od Lwowa poruszali w swoich pracach Jerzy Węgierski ${ }^{8}$ i Stanisław Pempel ${ }^{9}$, natomiast zagadnienia związane z Okręgiem IX Lwów Batalionów Chłopskich ściśle współdziałających z Rejonem V Obwodu AK „Mościska” omówione są w pracy Janusza Gmitruka, Piotra Matusaka i Witolda Wojdyły ${ }^{10}$. Słabo dostępny, ale niezwykle cenny jest artykuł Mieczysława Rychlickiego dotyczący oddziału partyzanckiego „Lech”"1.

Bezcenne okazały się maszynopisy wspomnień Ludwika Kurtycza „Mazurkiewicza” z roku 1974 pt. „Praca organizacyjna Obwodu Mościska” i z roku 1990 tegoż autora „Działalność konspiracyjna Obwodu AK Mościska”, korespondencja komendanta Obwodu z dowódcą Oddziału Leśnego „Lech” Zenonem Kubskim, także relacja pamiętnikarska z działań Rejonu V „Pnikut” napisana przez Franciszka Muszaka „Katona” w roku $1978^{12}$. W posiadaniu autora niniejszego artykułu znalazł się także życiorys oficera informacyjnego Obwodu AK Mościska Władysława Zielskiego „Dębowicza” z 1991 r., wraz z nekrologiem-wspomnieniem o nim napisanym przez Jerzego Bukowskiego, noszącym tytuł Strażnik Mogiły Mogit („Gazeta Wyborcza” - sierpień 2005).

W posiadaniu autora znalazły się ponadto relacje Anny Ziober „Tułaczka na Sybir - rozpacz i cierpienie" (Wrocław 1989), wspomnienie o gehennie

4 M. Pirożyński, Bernard Łubieński (1846-1933), Wrocław 1946.

5 Diecezja Przemyska w latach 1939-1945, t. 3: Zakony, red. J. Drau s, J. Mu siał, Przemyśl 1990.

${ }_{6}$ K. Nowakowski, Miasto Mościska - dzieje od nadania praw miejskich do wkroczenia Armii Czerwonej, „Kresy Południowo-Wschodnie. Rocznik Regionalnego Ośrodka Kultury Edukacji i Nauki” (Przemyśl), R. 2, 2004, z. 1.

7 M. Kozłowski, Między Sanem a Zbruczem. Walki o Lwów i Galicję Wschodniq 1918-1919, Kraków 1990; i d e m, Zapomniana wojna. Walki o Lwów i Galicję Wschodnią 1918-1919, Bydgoszcz 1999.

8 J. Węgi ierski, Obsada osobowa dowództw Lwowskiego Obszaru SZP-ZWZ-AK-NIE w latach 1939-1945, Kraków 2000.

$9 \quad$ S. Pempel, ZWZ-AK we Lwowie. 1939-1945, Warszawa 1990.

10 J. Gmitruk, P. Matusak, W. Woj dyło, Bataliony Chłopskie, Warszawa 1987.

11 M. Rychlicki, Historia powstania i działania OL „Lech”, „Szczecińskie Zeszyty Kresowe” 2009, VII-IX, X-XII.

12 W zbiorach autora. 
syberyjskiej Grzegorza Nowakowskiego opisane przez brata Michała w roku 1989, list z opisem życia łagiernika Antoniego Nowakowskiego (Gliwice 1989) oraz wspomnienie obozowe Sylwii Nowakowskiej o mężu łączniku AK Kazimierzu Nowakowskim (Jugów 1989).

Ponieważ pamięć o burzliwych dziejach miasta Mościska, starostwa i powiatu jest obecnie w Polsce mało znana, a Mościska kojarzą się w większości z przejściem granicznym z Ukrainą, warto przywrócić tę zapomnianą historię o polskich kresach Małopolski Wschodniej.

\section{Panowanie Rurykowiczów I KRólów Polski DO KOŃCA I RZECZYPOSPOLITEJ}

W czasach rządów kniaziów ruskich podległych Rusi Kijowskiej istniała pomiędzy Przemyślem a Lwowem miejscowość o nazwie Mostycz, rozciągnięta między wzgórzami nad rzeką Siczną (wcześniej zwaną Czarnym Potokiem lub Sieczną, dopływem Wiszni i dalej Sanu). Były tam stare przeprawy na rozlewiskach rzecznych i bagnach, do których prowadziły mosty.

Teren ten leżał na Rusi Halickiej i stanowił część księstwa przemyskiego rządzonego przez gałąź Rurykowiczów. W 1085 r. władcą przemyskim został z woli księcia wielkiego kijowskiego Wsiewołoda Jarosławicza Ruryk Rościsławicz. Ziemia przemyska była polską częścią Grodów Czerwieńskich, ale za czasów króla Bolesława Chrobrego znalazła się pod panowaniem Rusi ${ }^{13}$.

W roku 1099 książę kijowski Świętopełk Izasławicz próbował zdobyć Przemyśl i okoliczne ziemie wsparty przez wojska węgierskie, ale na polach nad rzeką Wiar przegrał bitwę z Wołodarem i Dawidem Igorowicami wspomaganymi przez Połowców. Natomiast w roku 1152 na brodach nad Sanem król węgierski Gejza II i oddziały księcia Izasława pokonały Włodymirka, który dostał się do niewoli. Rok 1206 rozpoczął rządy nad księstwami przemyskim i halickim braci Igorowiczów, potomków Igora Światosławicza z Siewierszczyzny. Duża bitwa rozegrała się nad rzeką Wiar blisko Mostycza w roku 1244. Drugie starcie o władanie całą Rusią rozegrało się między wojskami Daniela Halickiego i Rościsława Michałowicza - księcia kijowskiego wspomaganego przez księcia krakowskiego Bolesława Wstydliwego oraz króla węgierskiego Belę IV. Starcie wygrały oddziały księcia Daniela wspomagane przez wojska księcia Konrada Mazowieckiego i władcy Litwy Mendoga. Zwycięstwo w bitwie nad Sanem koło Jarosławia 17 sierpnia

13 T.A. Olszański, Zarys dziejów Rusi Halickiej i Karpackiej w wiekach średnich, Warszawa 1986, s. $54,59,61,78$. 
1245 r. zakończyło ostatecznie walki o księstwo włodzimiersko-halickie. Rywalizację z księciem Rościsławem wygrał Daniel Halicki wraz z bratem Wasylką.

Król halicki Daniel założył w roku 1237 na szlaku z Przemyśla do Kijowa miasto Lwów i przeniósł tam swoją stolicę. Za jego władztwa powstał Chełm (1256). Daniel przez ożenek związał się z Piastami mazowieckimi. Udało mu się na jakiś czas uniezależnić od Złotej Ordy i wzmocnić państwo, a jego dyplomacja nawiązała dobre kontakty z sąsiadami oraz zwróciła się w kierunku zachodnim.

Synowie Daniela, Lew i Andrzej, używali tytułu książąt, a królem tytułował się ich następca, wnuk Daniela Jerzy Lwowicz, który za stolicę państwa obrał Włodzimierz. Ostatnim władcą Rusi Włodzimiersko-Halickiej był otruty przez bojarów Bolesław Trojdenowicz, syn Marii z dynastii Romanowiczów, używający imienia Jerzy II. Władał Rusią w latach 1323-1340, a jego państwo istniało jako samodzielne do roku 1349. Podczas swoich rządów założył w roku 1339 na prawie magdeburskim miasto Sanok. Jerzy II został ożeniony z Eufemią, córką Giedymina, siostrą Aldony Anny, przez co jego szwagrem został Kazimierz III Wielki, syn Władysława Łokietka, króla Polski. W roku 1338 doszło w Wyszehradzie do zjazdu trzech władców środkowoeuropejskich: Jerzego II Trojdenowicza, Kazimierza III Wielkiego i Karola Roberta Andegaweńskiego. Przedmiotem spotkania były m.in. kwestia udzielenia pomocy Haliczowi i rozgromienia opozycji. Zaś najważniejszym tematem obrad było zawarcie układu w sprawie bezpotomnej śmierci Jerzego II. Halicz, po krewnym, miał dziedziczyć król Polski. To wkrótce nastąpiło, bo już w roku 1340, a Kazimierz nowe nabytki zaczął przejmować od Sanoka i Przemyśla wraz z miejscowością Mostycz oraz sąsiednią wsią Strzelczyska. Pod Mostyczem powstała pierwsza na Rusi misja dominikańska w Zakościelu z kościółkiem św. Michała. W latach 1340-1366 i 1371-1383 Rusią panował Lubart, młodszy syn Giedymina i Jewny. Król węgierski po śmierci Piasta ustanowił na Rusi swojego zarządcę - został nim palatyn węgierski książę Władysław Opolczyk, założyciel miast Jarosław (1375) oraz Drohobycz (1394). Po nim zarządzał Rusią zaufany króla Karola Roberta, książę halicki Ścibor ze Ściborzyc. Jadwiga usunęła z Rusi Ścibora i ogłosiła akt przyłączenia jej do Korony w roku $1387^{14}$.

Mąż królowej Polski Jadwigi Andegaweńskiej Władysław Jagiełło dostrzegł znaczenie strategiczne Mostycza i 21 października $1404 \mathrm{r}$. lokował tam na prawie magdeburskim miasto Mościska. Akt podpisali wicekanclerz Mikołaj, prepozyt kościoła św. Floriana w Krakowie, oraz m.in. wojewoda krakowski Jan Tarnowski,

14 Ibidem, s. 96-98; D. Dąbrowski, Rodowód Romanowiczów książąt halicko-wołyńskich, Poznań-Wrocław 2002, s. 203, 209, 222, 249; A. B rożyniak, Bitwa pod Jarosławiem i zjednoczenie Rusi Halicko-Wotyńskiej, „Prace Historyczno-Archiwalne” 2004, t. 14, s. 5-15; Wojny, bitwy, potyczki w średniowiecznej Polsce, red. P. B u nar, S. Sroka, Kraków 1996. 
starosta krakowski Klemens z Moskorzewa, kasztelan wojnicki Mikołaj z Michałowa oraz marszałek koronny Zbigniew z Brzezia. Osadźcą nowego miasta królewskiego został były wójt rzeszowski Mikołaj. Nowego wójta zobowiązano do zapłaty za nowy urząd oraz do budowy łacińskiego kościoła parafialnego św. Jana Chrzciciela. Mieszkańcy miasta otrzymali 60 łanów pól do uprawy i 60 lat wolnizny na zagospodarowanie. Ponadto ci, którzy postanowili karczować grunt oraz lasy w okolicy, dostali po 12 lat wolnizny. Po jej upływie mieli co roku z okazji święta św. Marcina przekazywać do skarbu królewskiego po jednej marce. Wójtowi powierzono władzę sądowniczą oraz powinność wystawiania własnego pocztu zbrojnego i stawiania się do służby na każde królewskie wezwanie ${ }^{15}$ :

\begin{abstract}
Wyjmujemy ponadto i zwalniamy na zawsze wójta, obywateli i innych mieszkańców miasta Mościszcze do wszelkiej jurysdykcji i władzy wszelkich kasztelanów naszego królestwa, sędziów, podsędków, kapitanów oraz wojewodów Ziemi Ruskiej i jakichkolwiek urzędników, aby przed nimi mięli odpowiadać w sprawach tak wielkich jak i małych. Obywatele i mieszkańcy Mościsk mięli być pociągani do odpowiedzialności tylko wobec swego wójta, który będzie w tym czasie miał władzę, a wójt przez nas, gdy będzie wezwany przez nasz list opieczętowany naszą pieczęcią, według prawa teutońskiego, czyli magdeburskiego ${ }^{16}$.
\end{abstract}

Tak oto Mościska stały się siedzibą starostwa niegrodowego, a przywileje lokacyjne potwierdzili kolejno królowie Kazimierz Jagiellończyk oraz Zygmunt August. Z uwagi na zagrożenie ze strony Wołochów, Tatarów i Kozaków starostowie królewscy wznieśli zamek, a miasto otoczyli wałami, fosami, bramami: Przemyską, Lwowską, Tkacką i Samborską. W skład starostwa mościskiego wchodziło 11 wiosek, ale teren ten początkowo był częścią starostwa przemyskiego. Pierwszym starostą został Jan Szczęsny Herburt, żyjący w latach 1567-1616, dyplomata, poeta, literat. Starosta ten popierał stronnictwo kanclerza Jana Zamoyskiego, później był jednym z przywódców rokoszu Zebrzydowskiego w roku 1607, uwięziony na dwa lata przez rojalistów. Wydał m.in. przywilej budowy cerkwi św. Jura w Mościskach w 1611 r. Jan Szczęsny z Felsztyna był też starostą dobromilskim, sanockim i sekretarzem królewskim. Nazywał siebie Rusinem i w swoich polemikach politycznych bronił prawosławia przed unitami. Jego rodzina pochodziła z Dolnej Saksonii, a także później Moraw i Śląska. Książę Władysław Opolczyk nadał rodzinie Herburta, a konkretnie Miklasowi i jego braciom, szereg ziem pomiędzy Strwiążem a Wiarem, Felsztynem oraz Dobromilem.

15 K. Nowakowski, op. cit., s. 42-46; A. Winiarski, Wieś Zakościele, Zakościele 1938, s. 3 (maszyn.); L. Po d horo de cki, Chanat Krymski i jego stosunki z Polska w XV-XVIII w., Warszawa 1987, s. 52-53; i d e m, Tatarzy, Warszawa 2010, s. 139-140.

16 J. Bielski, Kronika polska, Kraków 1597, s. 552. 
W latach 1607-1617 trwała szlachecka wojna o prawa do starostwa mościskiego i związanych z nim dochodów. Wojna o starostwo mościskie zaczęła się od napadu na miasto, kiedy starosta przemyski Adam Stadnicki z Leska spalił zamek, zniszczył wyposażenie i zbiory bezcennej biblioteki. W odwecie starosta Jan Szczęsny Herburt najechał na Przemyśl. Później rozpoczęła się regularna wojna między wojskami Jana Fredry a oddziałami kasztelana Maksymiliana Przerębskiego, pretendenta do starostwa. Kulminacją zatargów była bitwa pomiędzy Przemyślem a Dobromilem, zaś Jan Fredro uciekł z Mościsk. Przerębski ożenił się z wdową po staroście Herburcie Elżbietą, a jej oponentką była Zofia z Młyńskich Kopycińska, która wyszła za Jana Fredrę, zaś w sporze uczestniczyli Adam Stadnicki i Anna Mohylanka. Poruszony napadami i rabunkami król Zygmunt III Waza 25 października 1617 r. wydał specjalny uniwersał do starostów, podstarościch i burgrabiów ziem ruskich, ażeby „burzycieli spokoju publicznego więziono i pociągano do odpowiedzialności”"17.

Na przełomie wieków XV i XVI najeżdżali Mościska i okolice Wołosi (1468).

Pierwszy pomyślny okres rozwoju Mościsk przerwał w 1498 r. najazd Tatarów, którzy doszczętnie je spalili: „Oslam sułtan, brat stryjeczny Sudet Gereza rzucił się na Ruś Czerwoną i położył obóz pod Mościskami. Stąd puścił on trzydzieści tysięcy wojska w zagony, którzy w różnych stronach wielkie szkody poczynili, wsie i miasteczka podpalili, ludzi wiele pojmali. Czując, że się król Zygmunt ku nim ruszył, najazd od Mościsk odciągnęli”'18. Co do Tatarów, to w roku 1519 liczna armia krymska wpadła Czarnym Szlakiem za Bug, łupiąc województwo ruskie, bełskie i lubelskie.

Dobra mościskie 20 czerwca 1593 r. zostały oddzielone przez królewskich komisarzy od dóbr rodu Dunikowskich z Rudnik Starych i Nowych oraz Strzelczyc, odłączono też od nich Zakościele z dominikańską parafią św. Michała podległą jako filia mościskiej parafii św. Jana Chrzciciela. W położonej $3 \mathrm{~km}$ od Mościsk wsi Krysowice (własność Mniszchów) mieszkała w ojcowskich dobrach przyszła caryca Maryna Mniszchówna, żona uzurpatora Dymitra Samozwańca. Po zabójstwie pierwszego Dymitra pojawił się drugi - rozpoznany przez Marynę - car jako prawowity władca Moskwy (okres rosyjskich dymitriad).

W 1648 r. Tatarzy wraz z Kozakami rozłożyli się koszem w Mościskach, a następnie spustoszyli przedmieścia Lwowa, okoliczne wsie i ruszyli na Przemyśl. W najeździe uczestniczył Bohdan Zenobi Chmielnicki, hetman zaporoski, przywódca powstania przeciw Rzeczypospolitej, oraz Tuhaj-bej z rodu Arginów, zaufany chana Islama III Gereja.

17 W. Łoziński, op. cit., t. 2, s. 252-254; L. D zie dzicki, op. cit., 696; Zakościele, [w:] Słownik geograficzny Królestwa Polskiego..., t. 14, Warszawa 1895, s. 311.

18 L. Dziedzicki, op. cit., s. 695-696. 
Sierpień 1655 r. przyniósł Mościskom najazd Kozaków, którzy w bitwie pod Gródkiem rozbili wojska hetmana Stanisława Potockiego i splądrowali miasta ziemi lwowskiej. Chmielnickiego wspomagał ze swoimi oddziałami wódz moskiewski Wasyl Buturlin.

Oręż arsenału z zamku mościskiego przydał się w ostatniej bitwie, kiedy w roku 1673 rozbito pod Przemyślem zagony tatarskie. Wojny początków XVIII w. doprowadziły do sytuacji, gdy w Mościskach ubyło ok. 50\% budynków mieszkalnych, a część pozostała $\mathrm{w}$ ruinie. $\mathrm{W}$ tamtym czasie miasto posiadało rynek o rozmiarach 100 m długości i 100 m szerokości. Na jego środku znajdował się staw wysychający w lecie, a rynek otaczało siedem jatek. Wokół stało w XVII w. kilka kamieniczek z podcieniami, częściowo murowanych, piwnice i sklepy oraz 21 domów posiadających czworokątne podworce $\mathrm{z}$ wjazdami dla wozów. Tylko w dwóch domach mieszkała szlachta. Od XV w. Mościska posiadały w użytkowaniu grunty rolne przylegające do wsi Sułkowszczyzna i Rudki z pobliskim Zakościelem. Do XVII w. utrudniano Rusinom wyznania prawosławnego dostęp do urzędów miejskich, zaś ludność chłopską zobowiązano do pańszczyzny.

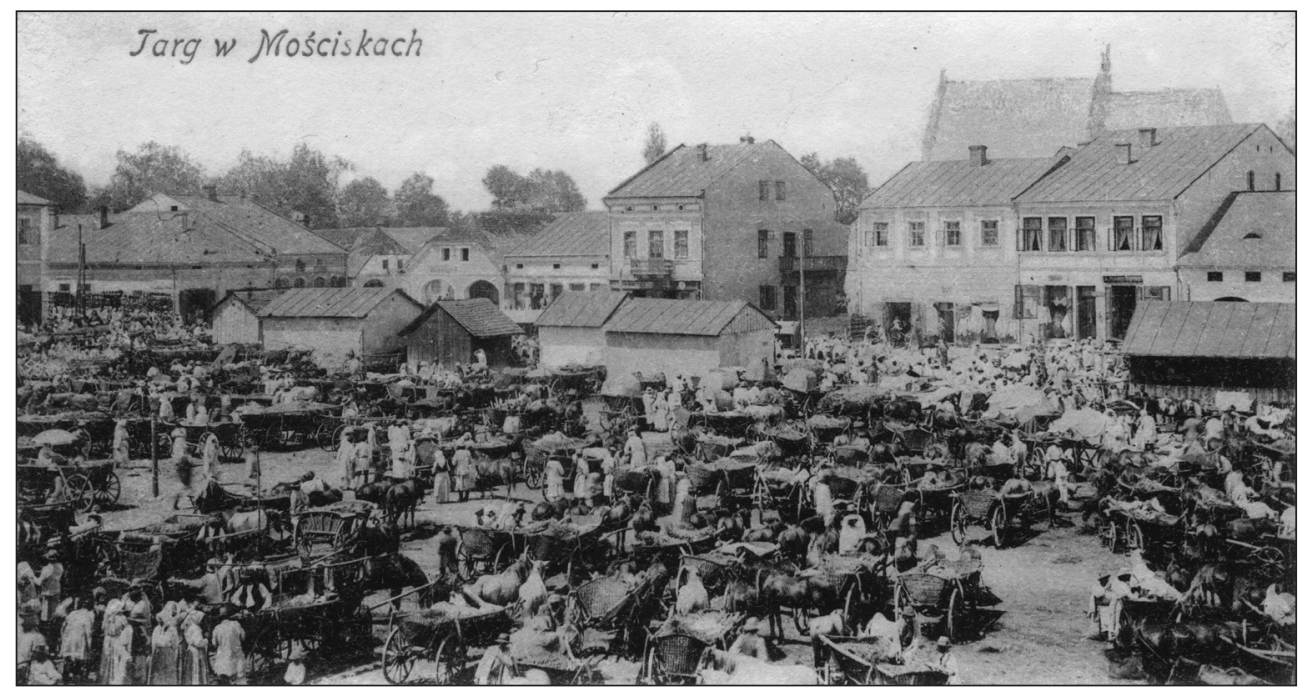

Rynek w Mościskch, pocz. XX w. - ze zbiorów FCDCN

W latach 1599-1603 wydzierżawiono Mościska i 13 wsi kupcowi gdańskiemu Jakubowi Semmerlingowi. Potem majątek posiadał Jan Szczęsny Herburt z Dobromila i Felsztyna. Po nim majątek przejął Maksymilian Przerębski, a po nim wdowa Anna Mohylanka Przerębska, hospodarówna mołdawska secundo voto Myszkowska, następnie Jan Stanisław Jabłonowski, Stanisław Rewera Potocki, Jan Jabłonowski, Jan Klemens Branicki i Izabela z Poniatowskich. 
Po upadku I Rzeczypospolitej pojawili się w mieście Izraelici, którzy za Mościskami posiadali cmentarz, a w samym mieście wybudowano synagogę i trzy domy modlitwy przy placu Berkowicza. Na przełomie XVI i XVII w. wzrosło znacznie znaczenie starostów, a urząd wójtowski stał się tytularny. Obowiązki sądowe zaczęli sprawować tak zwani landwójtowie, zaś wójtowie stracili swoje uprawnienia. W 1694 r. w urzędzie wójtowsko-ławniczym Mościsk zasiadało siedmiu ławników sprawujących władzę ekonomiczną o znikomych uprawnieniach administracyjno-sądowych. Do starostwa należały Czarniawa, Sokola, Małnów, Strzelczyce, Rzadkowice, Zakościele, Arłamowska Wola, Wola Rudnicka, Sarny, a także folwark w Mościskach, Rudniki.

\section{Czas rozbiorów}

W czasie pierwszego rozbioru starostwo mościskie wykupił od władz austriackich Ignacy hrabia Cetner, który przejęty zamek kazał przebudować na pałac. Ostatni z Cetnerów Alfred za długi karciane dobra kameralne odstąpił w roku 1909 Ludwikowi hrabiemu Dębińskiemu, ten zaś dzięki pomocy banku w Łańcucie po dwóch latach zarządu majątkiem przeprowadził parcelację i rozbiórkę pałacu.

Mościska, położone na szlaku handlowym z zachodu na południowy wschód oraz północny zachód, stosunkowo szybko dzięki jarmarkom i targom stały się ważnym ośrodkiem handlu końmi, sznurkami, skórami, woskiem, solą oraz potażem i płótnami, a także słynnymi fujarkami wytwarzanymi w pobliskim Jaworowie. Od tych fujarek mościszczan, którzy słynęli z poczucia humoru, nazywano „fujarami z Mościsk”. Płótna wytwarzane w mościskich tkalniach od XVIII w. przez Przemyśl trafiały rzeką do Gdańska. W mieście istniało 8 cechów skupiających krawców, bednarzy, 26 tkaczy, 91 rzeźników i 30 szewców. Funkcjonowało też 7 jatek, 4 warsztaty kowalskie i ciesielskie, działalność prowadziło kilku medyków, kuśnierzy, ślusarzy. Działał także duży cech piekarzy, jak również miecznicy, sztycharze, iglarze, błoniarze. W mieście była ponadto cegielnia oraz warsztaty: złotnicze, garncarskie i szklarskie.

W roku 1787 władza austriacka oddała część starostwa mościskiego Ignacemu hrabiemu Cetnerowi jako odszkodowanie za przejęcie Nadwórnej. U schyłku XVIII w. społeczność Mościsk liczyła 2240 mieszkańców, w tym 1300 rzymskich katolików, 200 grekokatolików oraz 700 żydów. Na początku XX w. liczebność mościszczan wzrosła do 4590 osób, w tym 2100 żydów, 2000 łacinników oraz 490 grekokatolików. Za burmistrza Wiktora Krukowskiego zasypano dół po stawie, obniżając poziom rynku tak, że Żydzi musieli do swoich domów domurować schody. Plac rynkowy został wybrukowany kamieniami nazywanymi popularnie 
kocimi łbami. Dookoła rynku znajdowały się murowane podcienia, gdzie odbywały się targi i jarmarki. Podcienia w latach 20 . XX w. zamurowali ich właściciele ${ }^{19}$. W roku 1872 urodził się w Mościskach słynny wynalazca Jan Szczepanik, nazywany „polskim Edisonem”, który skonstruował maszynę żakarda, elektryczny odbiornik telewizyjny zwany teleskopem projekcji diaskopolowej barwnej, kolorymetr optyczny do zapisywania dźwięków oraz stworzył barwny film, którego budowa oparta została na systemie addytywnym. Konstruktor posiadał pracownię w Tarnowie i tam zmarł.

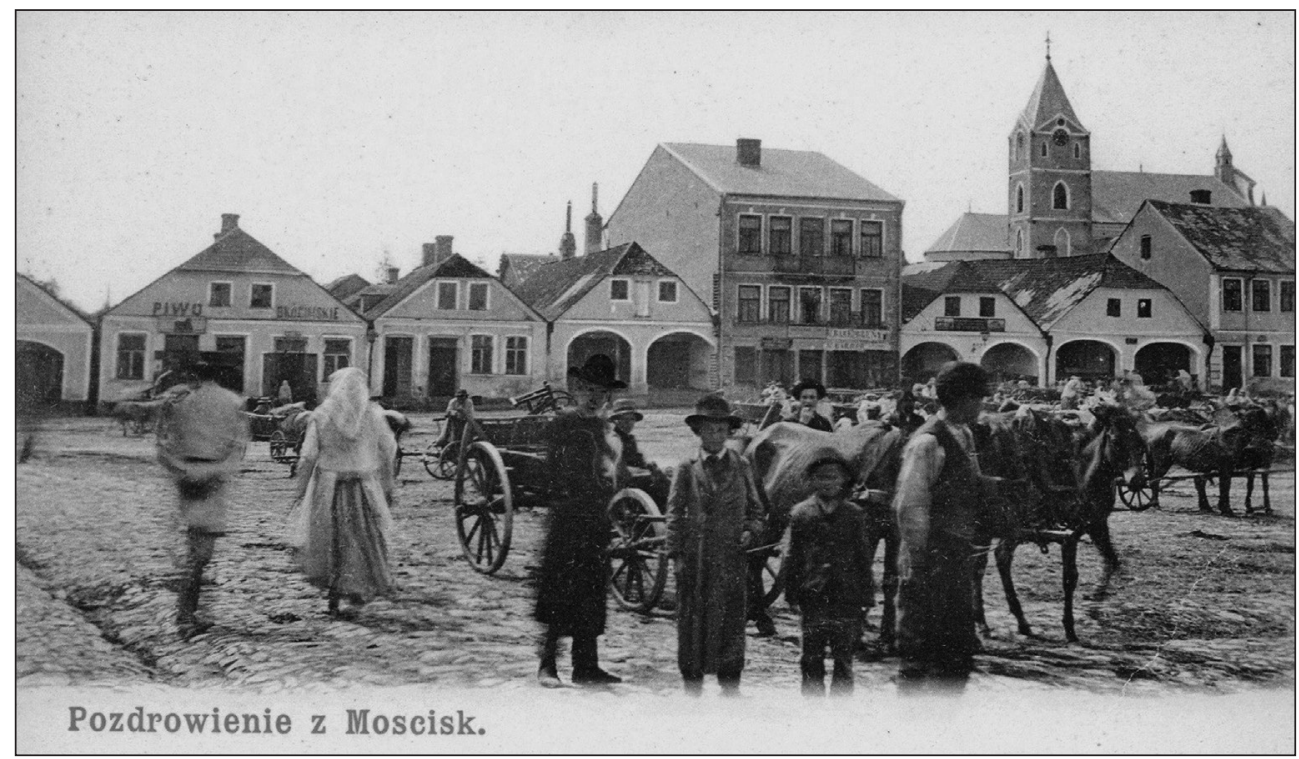

Rynek w Mościskach - ze zbiorów Z. Franczukowskiego, kresy.org.pl

Po zajęciu przez Austriaków południa Polski terytoria zabrane w pierwszym rozbiorze nazwano Księstwem Galicji i Lodomerii ze Śląskiem Cieszyńskim. Określenie to nawiązywało do nazwy ruskiego księstwa włodzimiersko-halickiego i zostało przywołane dla zalegalizowania zaboru ziemi, do której miało prawa królestwo węgierskie w średniowieczu, w związku z układem zawartym pomiędzy władcą Rusi, Królestwem Polskim a Królestwem Węgier.

Mościska leżały w pobliżu Przemyśla, który dla okolicznych miejscowości stał się centrum kultywowania tradycji narodowych i niepodległościowych; stąd wychodzili na wojny napoleońskie liczni ochotnicy, a w roku 1831 młodzież przedzierała się walczyć w korpusie gen. Dwernickiego w lutym, marcu i kwietniu (bitwa pod Boremlem). Ułanem był Sebastian Nowakowski z Zakościela, który

19 Ibidem, s. 693-702, K. Nowakowski, op. cit., s. 47-50. 
potem przez jakiś czas ukrywał się z kolegą szwadronowym na Podolu ${ }^{20}$. Przemyśl był liderem w zakładaniu związków patriotycznych, m.in. Młodej Sarmacji, Związku Synów Ojczyzny, Związku Demokratów Wojskowych, w okresie Wiosny Ludów Okręgowej Rady Narodowej. Podczas powstania styczniowego solidaryzowano się z ruchami niepodległościowymi i rewolucyjnymi. Nad Sanem w roku 1863 powstało zaplecze dla oddziału partyzanckiego płk. Marcina Lelewela-Borelowskiego ${ }^{21}$.

Dużym wydarzeniem był początek budowy ważnej strategicznie Twierdzy Przemyśl, trzeciej w Europie po Antwerpii i Verdun (etapy rozbudowy: 1878, $1881-1886)^{22}$.

Bardzo ważne było też powstanie szlaku komunikacyjnego, co miało decydujący wpływ na rozwój ekonomiczno-gospodarczy Mościsk. Była to trakcja kolejowa (linia galicyjska) im. Karola Ludwika, która połączyła miasto z Przemyślem i Lwowem. Prace budowlane nad torowiskiem, stacjami, mostami i przepustami zakończono w roku 1861 i 4 listopada tegoż roku odbyło się uroczyste oddanie do użytku pierwszej linii kolejowej. Galicyjska kolej pozostawała pod zarządem Leona księcia Sapiehy, a 1 stycznia 1892 r. przeszła pod jurysdykcję Cesarsko-Królewskiej Kolei Państwowej. Pomysłodawcą projektu i prezesem kolei Karola Ludwika był Włodzimierz hrabia Borkowski, członek Stanów Galicyjskich, kurator Galicyjskiej Kasy Oszczędnościowej, zmarły w Rudnikach w posiadłości Edwarda hrabiego Chołoniewskiego.

We wrześniu 1880 r. na polach między twierdzą przemyską a starostwem mościskim doszło do przeprowadzonych na dużą skalę ćwiczeń wojskowych w związku ze spodziewanym kryzysem wojennym. Do Krysowic pod Mościskami przybył obserwować manewry cesarz Franciszek Józef - parę dni przebywał tam w pałacu podobno najpiękniejszym w Galicji, ze wspaniałym założeniem parkowo-ogrodowym. Od hrabiów Mniszchów majątek w Krysowicach przejęli wcześniej hrabiowie Stadniccy, a cesarza gościł Stanisław hrabia Stadnicki.

Po wkroczeniu z wojskiem zaborczym austriackich urzędników zaczął się rabunek polskich majątków, królewszczyzn, kasata zakonów i sprzedaż na licytacjach. W Mościskach sprzedano klasztor dominikanów, za zgodą cesarza monarchii austriackiej Józefa II i z protekcją Agenora hrabiego Gołuchowskiego, który zakupili Żydzi na skład drewna i innych materiałów. Dzięki składkom ludności powiatu mościskiego budynek klasztoru został odkupiony w roku 1881

20 D. Ostapowicz, Boreml 1831, Warszawa 2010, s. 97-109.

21 L.M. Włodek, Niepodległość trzeba było wywalczyć, „Życie Przemyskie” 1989, nr 4 (XI), s. 1.

22 J. Rożański, Przemyśl i okolice, Warszawa 1986, s. 66; T. Idzikowski, Twierdza Przemyśl, Przemyśl 2005, s. 6-7. 
i gruntownie wyremontowany. Postanowiono sprowadzić do niego ojców redemptorystów za pośrednictwem prezbitra o. Bernarda Łubieńskiego przebywającego w Rzymie. Otrzymał on na audiencji u Ojca Świętego Leona XIII papieskie błogosławieństwo dla utworzenia Zgromadzenia Najświętszego Odkupiciela oraz kopię ikony Matki Boskiej Nieustającej Pomocy przechowywanej w Rzymie. Obraz przeznaczony był dla kościoła Redemptorystów w Mościskach, gdzie znajduje się do dzisiaj.

Ojciec Bernard założył w Mościskach pierwszy na ziemiach polskich klasztor synów św. Alfonsa, sam też został nazwany apostołem Polski. Był kaznodzieją, misjonarzem, pisarzem, rektorem domu zakonnego w Mościskach i krzewicielem kultu ikony Matki Boskiej Nieustającej Pomocy. Po Mościskach kolejne placówki zgromadzenia utworzono w Tuchowie, Krakowie i Lwowie, a także w Warszawie. $\mathrm{Z}$ tego powodu w Mościskach znalazła siedzibę polska wiceprowincja, która zainaugurowała działalność 16 października 1894 r. W tamtym czasie było w klasztorze siedmiu braci. Rok później utworzono małe seminarium, a w 1899 powstał polski nowicjat, cztery lata później redemptoryści utworzyli własne seminarium duchowne. Ponieważ zakon rozwijał się szybko, obejmując ziemie wszystkich zaborów, w 1909 r. rangę wiceprowincji podniesiono do polskiej prowincji. Od roku 1883 superiorem kościoła pod wezwaniem św. Katarzyny Aleksandryjskiej był o. Antoni Jedeka, wikarym ks. Ludwik Pogłudek. Rektor o. Bernard założył Bractwo św. Rodziny dla młodzieży męskiej i Bractwo Najświętszego Sakramentu obchodzące swoje święto w dniu św. Stanisława Kostki, 13 listopada ${ }^{23}$.

W roku 1897 rozebrano drewniany kościół św. Michała w Zakościelu, a trzy lata później postawiono nowy, murowany. Fundusze zbierano w całej Galicji dzięki inicjatywie proboszcza parafii w Mościskach ks. kan. Alfreda Białogłowskiego, który z ks. bp. Józefem Sebastianem Pelczarem z Przemyśla poświęcił go 29 września 1900 r. W roku 1884 redemptoryści zaczęli głosić kazania w Lackiej $\mathrm{Woli}^{24}$.

Częstymi gośćmi klasztoru byli rektor seminarium duchownego w Przemyślu ks. Jan Puzyna, a także ks. Bronisław Markiewicz, założyciel zakonu michaelitów. Na rekolekcje przyjeżdżali od roku 1890: książę Sapieha z Siedlisk, książę Adam Sapieha ze Lwowa, Zygmunt hrabia Zamoyski z Wysocka, Władysław hrabia Zamoyski, Stanisław hrabia Zamoyski z Podzamcza, ks. bp Kossakowski z Włocławka, ks. bp nominat Arnold Nowak, sufragan krakowski, ks. abp Wincenty Popiel z Warszawy i inni ${ }^{25}$.

23 M. Pirożyński, op. cit.

24 A. Winiarski, op. cit., s. 8.

25 M. Pirożyński, op. cit. 


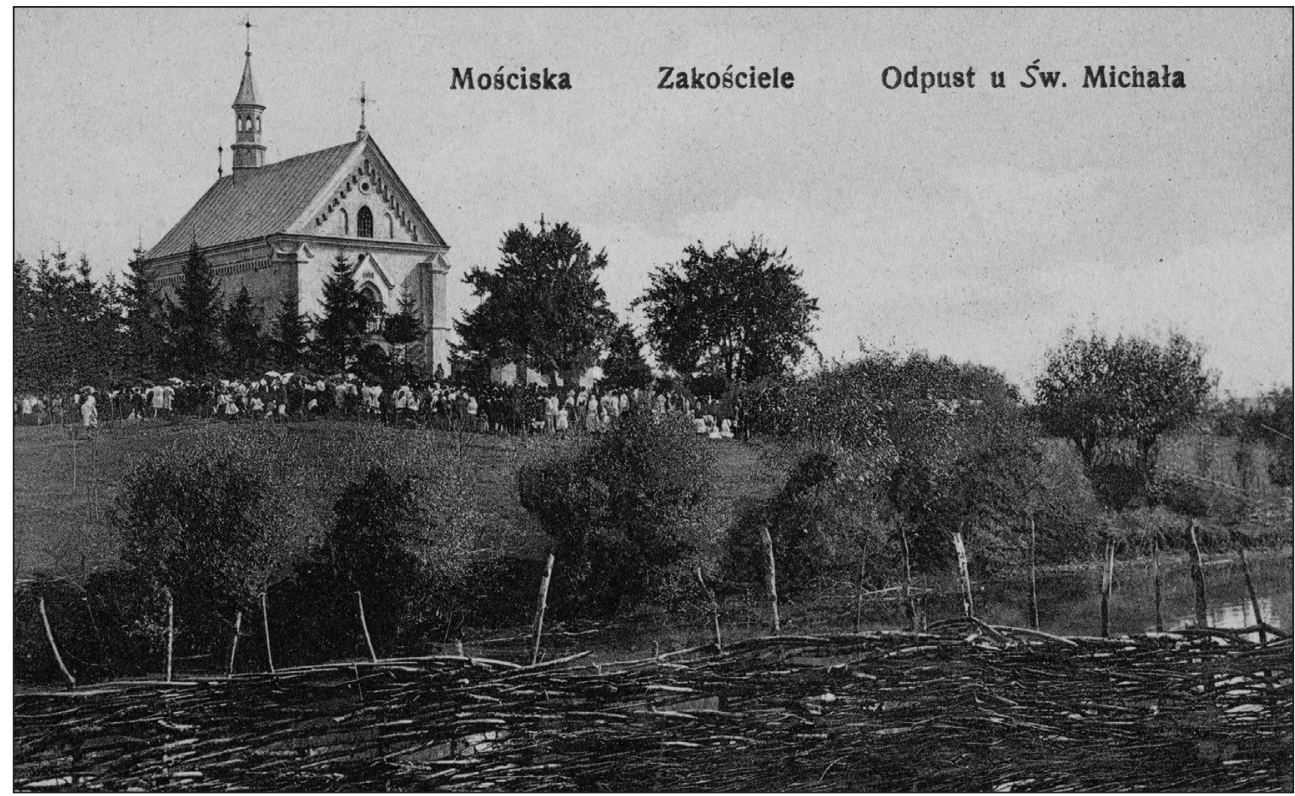

Kościół pw. św. Michała w Zakościelu - ze zbiorów Z. Franczukowskiego, kresy.org.pl

Dzieje edukacji w Mościskach zaczęły się od powołania w roku 1870 szkoły przy klasztorze podominikańskim, od roku 1882 istniała szkoła etatowa męska czteroklasowa, a od 1894 r. szkoła sześcioklasowa im. króla Jan III Sobieskiego i jednoklasowa szkoła etatowa żeńska im. królowej Jadwigi. Oprócz szkół miało

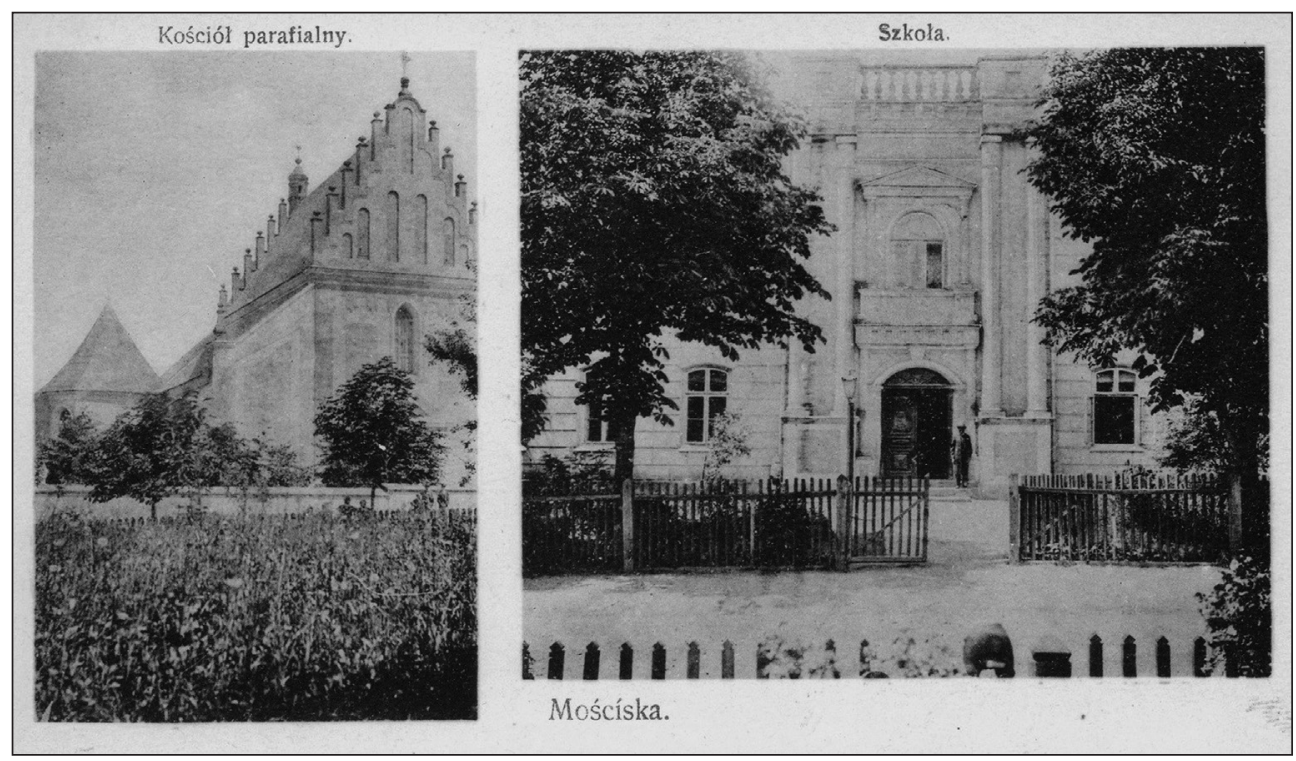

Kościół parafialny i szkoła w Mościskach - ze zbiorów Z. Franczukowskiego, kresy.org.pl 
w centrum Mościsk publiczne budynki starostwo i urząd podatkowy. W Zakościelu, w domu Michała Gawlika, przy Kole Rolniczym zaczęła funkcjonować w 1893 r. Kasa Banku Raiffeisena.

Polaków w powiecie mościskim było do I wojny światowej $60 \%$, ostoją polskości był zawsze Kościół katolicki; mieszkaniec ochrzczony w obrządku łacińskim był uznawany za Polaka, zaś ochrzczony w cerkwi greckokatolickiej był Rusinem-Ukraińcem, od roku 1918 wyłącznie Ukraińcem. Żydzi mieli swoją synagogę i gminę oraz sztetl i nazywali też siebie Izraelitami. Mniejszości narodowe stanowiły ok. 40\% i każda z nich posługiwała się swoim językiem oraz kultywowała własne tradycje, kulturę oraz historię. Gdy sąsiad przychodził do sąsiada, to mówił tak, jak nauczyła go matka w jego języku. Polacy zaś rozumieli język ruski-ukraiński, a Rusini-Ukraińcy polski. Miasto było polskie, a wieś w większości ruska. Polacy odwiedzali cerkwie i obchodzili najważniejsze święta i odwrotnie - Rusini szli do kościołów. Jeśli w rodzinie mieszanej ojciec był Polakiem i miał syna, to syn był chrzczony w kościele, a kiedy matka była Rusinką, córkę chrzczono cerkwi - i odwrotnie.

W szkole językiem wykładowym był polski, wszystkie dzieci miały polski elementarz w pierwszej klasie, w drugiej ruski, a te uczęszczające do szkoły w mieście w trzeciej klasie uczyły się niemieckiego. Na wsiach w czwartej klasie nie było niemieckiego, w klasach ruskich elementarz w pierwszej klasie był ruski, a w drugiej polski. Dzieci musiały pisać i po polsku, i po rusku. Na lekcjach, kiedy większość się modliła, żydzi stali, nikt z nich nic nie mówił - ani koledzy, ani nauczyciel. Podczas spaceru księża obu wyznań oraz rabin spacerowali razem i rozmawiali. Dzieci tak samo razem się bawiły. W niedzielę dzieci ze szkoły w mieście szły razem obowiązkowo parami do kościoła i z kościoła, z dwoma nauczycielami na przodzie jako dyżurnymi i dwoma z tyłu. I choć dzieci było ok. 300, to szły cicho, bez hałasu. Świętowano w sobotę i w niedzielę. Rusini szli do cerkwi w sobotę, podobnie Żydzi do synagogi.

Co do wyznania Polaków i Rusinów, religia była jedna, ale obrządek inny nie zwracano jednak na to uwagi. Polacy zachodzili do cerkwi, a Rusini do kościoła. Ze świąt ruskich najważniejsze było święto Jordanu 19 stycznia, w którym Polacy również brali udział. Księża polscy i ruscy witali się i razem szli święcić wodę w rzece lub studni. Po poświęceniu wody proboszcz ruski dawał koledze polskiemu prowadzić procesję do cerkwi, a on brał kociołek z wodą święconą i szedł kropić i kadzić - był to obrzęd tak zwanego poświęcenia domów; udawał się do starostwa, sądu, urzędu finansowego, magistratu i szkół (bo były dwie). Później miejscowy proboszcz zapraszał księży do siebie w gościnę. Gdy nadchodziło Boże Ciało, to polscy księża zapraszali do siebie ruskiego proboszcza, by 
wraz ze swoimi ludźmi brał udział w uroczystości i procesji, czytał jedną z Ewangelii, czyli śpiewał w swoim obrządku np. Ewangelię św. Marka. Po procesji polscy księża zapraszali ruskich w gościnę. Rusini po kolędzie przychodzili do Mościsk z Laszek Gościńcowych, siedmiu chłopców bardzo ładnie śpiewało wówczas na głosy. U nich święta wigilijne przypadały 6 stycznia i wtedy polscy chłopcy (i nie tylko) szli kolędować do Laszek czy Pakości. Tak samo było w Święta Wielkanocne - nawzajem się odwiedzano i goszczono.

Ale kiedy nadszedł rok 1918, widoczne już były różne utarczki - politycy austriaccy i ruscy zaczęli podburzać narody jeden przeciw drugiemu i siać wzajemną nienawiść. Choć wtedy jeszcze było w miarę spokojnie.

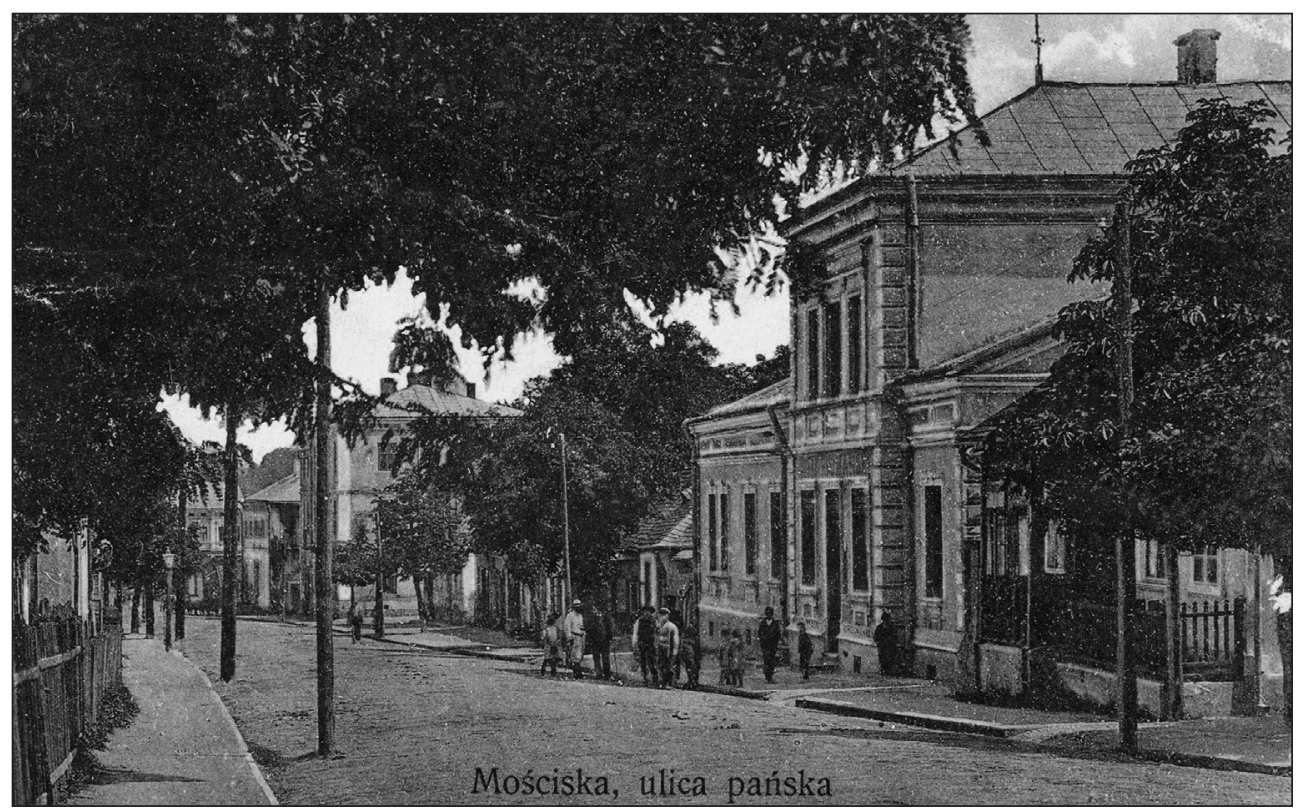

Mościska, ul. Pańska - ze zbiorów Z. Franczukowskiego, kresy.org.pl

\section{WOJNA ŚWIATOWA}

Wiek XX, obok lokalnych konfliktów zbrojnych, jak np. wojny bałkańskie w latach 1912-1913 i rywalizacja Rosji i Austro-Węgier o przejęcie państw na Bałkanach, przyniósł wielkie konflikty zbrojne nazwane wojnami światowymi. Przyczyną nasilenia się europejskich niepokojów stała się chęć odzyskania przez Francję Alzacji i Lotaryngii, utrzymania przez Wielką Brytanię wpływów na Bliskim Wschodzie oraz w Turcji, wreszcie nasilony antagonizm o kolonie w krajach afrykańskich.

Poprzez działania bałkańskie i roszczenia austriackie wobec Serbii pokój prysnął jak bańka mydlana po zamachu na następcę tronu habsburskiego arcyksięcia 
Franciszka Ferdynanda i jego żonę Zofię, co miało miejsce 28 czerwca 1914 r. w Sarajewie. Po złożeniu przez monarchię austro-węgierską ultimatum Serbii Rosja stanęła po stronie tej ostatniej. Do 3 sierpnia Rosji wypowiedziały wojnę Austro-Węgry i Niemcy. Początkowo terenem działań wojennych było Królestwo Polskie, później Galicja Zachodnia. Po przegranych bitwach 1914 r. pod Lwowem 6 września i pod Rawą Ruską 11 września naczelne dowództwo austriackie zarządziło na 12 września odwrót na zachód. Po odrzuceniu propozycji złożenia broni i poddania się twierdzy przemyskiej rosyjskie wojska zaczęły otaczać Przemyśl. Dnia 17 września rozpoczęło się oblężenie twierdzy. Dzień wcześniej do Mościsk i okolicznych wsi wkroczyły wojska rosyjskie z oddziałami Kozaków oraz Czerkiesów. Sztab i dowództwo wojsk oblężniczych rozlokowało się w pałacach ochmistrza cesarskiego hrabiego Chołoniewskiego w Rudnikach i hrabiego Stadnickiego w Krysowicach. Mościska podzielono na następujące dzielnice: Lwowska, Podmiasto, Hyclówka (grupa domów), folwark Dolina, Kotówka, cegielnia i Jaworowiec. Znalazły się one w bezpośrednim pasie przyfrontowym. Wraz z nadejściem wojsk dość szybko rozprzestrzeniały się zakaźne choroby: cholera, groźne odmiany czerwonki; w zastraszającym tempie rósł procent mieszkańców powiatu mościskiego, którzy ulegli zakażeniom. Od stycznia do czerwca 1915 r. tylko na samą cholerę w parafii Mościska zmarło ok. 300 osób. Wojna, która dotarła do powiatu mościskiego, wygnała z rodzinnych domów Mościszczan do Rosji, na Syberię, do Rumunii, państw azjatyckich i afrykańskich, a nawet do Australii. Od samego początku okupacji rosyjskiej zaczęła działać żandarmeria polowa, jej oddziały dokonały przeszukania m.in. pomieszczeń klasztoru redemptorystów. W klasztorze próbowano zorganizować szpital wojskowy. Przed frontem uciekła na zachód część księży wraz z wikarym i bracia zakonni. Dnia 1 stycznia 1915 r. przyjechali do Mościsk i zainstalowali się na zakościelskich błoniach wojskowi piekarze, którzy po cichu sprzedawali ludności chleb żytni razowy za 20 kopiejek, a pszenny razowy za 30 kopiejek. Ludność kupowała ten chleb i suszyła, aby tym sposobem uchronić się od głodu, gdyż ich zboża jesienią zniszczyli Kozacy. Dnia 20 lutego 1915 r. aresztowano i wywieziono w głąb Rosji trzech ojców i dwóch braci redemptorystów. Okupacja rosyjska trwała prawie dziewięć miesięcy:

Wnet i Mościska znalazły się w strefie bojowej. Z końcem maja doszło do bardzo zaciętych walk trwających dwa tygodnie. Dzień w dzień grzmiały armaty, syczały szrapnele, pękały granaty, lecz ani kościołowi, ani klasztorowi żadnej szkody ostrzał nie wyrządził. Największą panikę szerzyły samoloty, które raz po raz zrzucały bomby. W maju kilka samolotów austriackich bombardowało miasto. Kilkanaście bomb spadło w pobliżu kościoła, jednak nic go nie uszkodziło ${ }^{26}$.

26 Ibidem, s. 200. 
Uszkodzili go natomiast Kozacy podczas dość mroźnej i trwającej do kwietnia zimy; także ograbili wyposażenie kościołów. Spalono wszystkie meble i książki, m.in. z miejskiej biblioteki. Ogrzewano się, nocując i paląc ogniska w budynkach kościelnych. Wiele rzeczy uległo grabieży, skonfiskowano dzwony i wszelki złom, materiały budowlane oraz wyposażenie mościskiej cegielni. Dewastacji uległy pałace, dwory i gmachy użyteczności publicznej. Zaginęła kopia cudownej ikony Matki Boskiej Nieustającej Pomocy przywieziona z Rzymu.

Generał Dmitrij Szczerbaczow, mając pod rozkazami 133 oficerów liniowych, dowodził kolejnymi szturmami na umocnienia twierdzy przemyskiej. Dnia 3 października przystąpiono do pierwszego szturmu od strony wschodniej twierdzy i pomimo że żołnierzom rosyjskim po zaciętej walce udało się wedrzeć do fortów, to obrońcy stosunkowo szybko odparli atak, otaczając jednostki wroga i pokonując je. Kilka dni później, 8 października, został przeprowadzony drugi szturm, od strony północnej, lecz tym razem wojskom rosyjskim nie udało się zbliżyć nawet do linii zasieków i cała operacja zakończyła się 10 października porażką. Kolejny szturm podjęto 6 listopada. I tym razem nie doszło do bezpośrednich walk, lecz rosyjska armia otoczyła ściśle miasto Przemyśl, odcinając możliwość dostarczania załodze twierdzy zaopatrzenia. Mroźna zima zadziałała na obrońców szybko i skutecznie. Gwałtowne zmniejszenie racji żywnościowych zmusiło Austriaków do uboju 10 tys. koni będących na etacie zaopatrzenia. Coraz więcej żołnierzy armii austro-węgierskiej zaczęło zapadać na różne choroby, nasiliła się dezercja. Z 17 na 19 marca 1915 r. dokonano nieudanej próby przebicia się przez linie nieprzyjacielskie, na co odpowiedziano totalnym szturmem ze wszystkich stron twierdzy. Choć jeszcze zdołano się obronić, to 23 marca dowództwo twierdzy z gen. Hermanem Kusmankiem podpisało akt kapitulacji, a pięć dni później przystąpiono do likwidacji magazynów z zaopatrzeniem w resztki żywności, materiałami wojskowymi, amunicją, uszkodzono broń, wysadzono działa i mosty na Sanie. Wkrótce do Przemyśla wkroczyły zwycięskie wojska, a 4 kwietnia przyjechał odwiedzić zdobyte miasto car Mikołaj II.

W wyniku bitwy pod Gorlicami, nazwanej przełomem gorlickim, przerwano front i za cofającymi się Rosjanami ruszyła w kierunku wschodnim ofensywa. Uciekające wojska zamknęły się w twierdzy przemyskiej, budując nowe linie umocnień w oparciu o zachowane forty w celu odparcia ataku. Dnia 18 maja Przemyśl został otoczony przez oddziały wojsk austro-węgierskich i niemieckich, a 31 maja rozpoczął się ostateczny atak i 3 czerwca, od strony Zasania, zaczęly wkraczać pułki bawarskie, od zachodu natomiast 4 austriacka dywizja kawalerii. Na lustrację odbitej twierdzy 6 czerwca przybył głównodowodzący wojsk austro-węgierskich marszałek polny arcyksiążę Fryderyk ${ }^{27}$.

27 T. Idzikowski, op. cit., s. 8-11. 
Straty poniesione przy szturmach to 10 tys. zabitych, rannych i zaginionych, zaś straty będące skutkiem próby przebicia się z oblężenia wyniosły 6,8 tys. austriackich żołnierzy oraz 1282 rannych i 290 zaginionych. Obopólny bilans strat był ogromny, przelało się wiele krwi żołnierskiej.

5 maja została przełamana ofensywa rosyjska pod Gorlicami przez wojska austro-węgierskie i niemieckie, wycofujące się wojska rosyjskie spod Gorlic niosły ze sobą straszną zarazę - cholerę azjatycką, na którą zmarło w Zakościelu 36 osób. Chory żył tylko 8 godzin i kończył życie w skurczach żołądka, rąk i nóg, wymiotach, biegunce, cały robił się fioletowy, ale po śmierci wybielał... Powstały też inne choroby jak tyfus, czerwonka, na którą wymarła cała rodzina Drzewieckich, na dole koło Anny Rudy, gdzie mieszkał w tym domu Fajfur Jan w 1917 r. wybuchła nowa choroba hiszpanka. 13 czerwca 1915 r. opuścili Rosjanie Zakościele, przyszli znowu Austriacy i zaczęli na nowo rekwirować wszystko, co się dało. Brali wszystko - zboże, siano, ziemniaki, bydło, podwody, samych ziemniaków zebrali w jednym roku 12 wagonów. Znowu trzeba było kryć, a robić nie było komu, bo ojcowie byli na wojnie. W roku 1916 zabrali do wojska wszystkich mężczyzn, pozostały prawie same kobiety i dzieci, a i tych obdzierano z materiałów, płótna i bielizny. Przy końcu wojny, to i wojsko miało głód, sami chleb wypiekali z mąki kukurydzianej, trotów i perzu, a po miastach, zwłaszcza tych większych też nie było lepiejej ${ }^{28}$.

Dnia 14 czerwca do miasta wkroczyli Austriacy. Ojciec Łubieński zorganizował rekolekcje w Twierdzy, Myślatyczach i Pnikucie oraz w kościele klasztoru Redemptorystów; do komunii przystąpiło ok. 600 osób.

Z kolei 7 czerwca 1916 r., w rocznicę odnalezienia ikony Matki Boskiej Nieustającej Pomocy, w Mościskach urządzono wspaniałe, trzydniowe uroczystości i nabożeństwo, uroczystą mszę świętą celebrowali po kolei księża biskupi Pelczar, Fischer i Nowak ${ }^{29}$.

\section{BIBLIOGRAFIA}

Bielski J., Kronika polska, Kraków 1597.

Brożyniak A., Bitwa pod Jarosławiem i zjednoczenie Rusi Halicko-Wołyńskiej, „Prace Historyczno-Archiwalne" 2004, t. 14.

Dąbrowski D., Rodowód Romanowiczów książąt halicko-wołyńskich, Poznań-Wrocław 2002. Diecezja Przemyska w latach 1939-1945, t. 3: Zakony, red. J. Draus, J. Musiał, Przemyśl 1990. Dziedzicki L., Mościska, [w:] Słownik geograficzny Królestwa Polskiego i innych krajów słowiańskich, red. B. Chlebowski et al., t. 6, Warszawa 1885.

Gmitruk J., Matusak P., Wojdyło W., Bataliony Chłopskie, Warszawa 1987.

28 A. Winiarski, op. cit., s. 14.

29 M. Pirożyński, op. cit., s. 199-200; A. Winiarski, op. cit., s. 7-8, 51-53. 
Idzikowski T., Twierdza Przemyśl, Przemyśl 2005.

Kozłowski M., Między Sanem a Zbruczem. Walki o Lwów i Galicję Wschodnia 1918-1919, Kraków 1990.

Kozłowski M., Zapomniana wojna. Walki o Lwów i Galicję Wschodniq 1918-1919, Bydgoszcz 1999.

Łoziński W., Prawem i lewem - obyczaje na Rusi Czerwonej w pierwszej połowie XVII wieku, t. 2: Wojny prywatne, Lwów 1931.

Nowakowski K., Miasto Mościska - dzieje od nadania praw miejskich do wkroczenia Armii Czerwonej, „Kresy Południowo-Wschodnie. Rocznik Regionalnego Ośrodka Kultury Edukacji i Nauki” (Przemyśl), R. 2, 2004, z. 1.

Olszański T.A., Zarys dziejów Rusi Halickiej i Karpackiej w wiekach średnich, Warszawa 1986.

Orłowicz M., Ilustrowany przewodnik po Galicji, Bukowinie, Spiszu, Orawie i Ślasku Cieszyńskim, Lwów 1919.

Ostapowicz D., Boreml 1831, Warszawa 2010.

Pempel S., ZWZ-AK we Lwowie. 1939-1945, Warszawa 1990.

Pirożyński M., Bernard Łubieński (1846-1933), Wrocław 1946.

Podhorodecki L., Chanat Krymski i jego stosunki z Polska w XV-XVIII w., Warszawa 1987.

Podhorodecki L., Tatarzy, Warszawa 2010.

Rożański J., Przemyśl i okolice, Warszawa 1986.

Rychlicki M., Historia powstania i działania OL „Lech”, „Szczecińskie Zeszyty Kresowe” 2009, VII-IX, X-XII.

Węgierski J., Obsada osobowa dowództw Lwowskiego Obszaru SZP-ZWZ-AK-NIE w latach 1939-1945, Kraków 2000.

Winiarski A., Wieś Zakościele, Zakościele 1938 (maszyn.).

Włodek L.M., Niepodległość trzeba było wywalczyć, „Życie Przemyskie” 1989, nr 4 (XI).

Wojny, bitwy, potyczki w średniowiecznej Polsce, red. P. Bunar, S. Sroka, Kraków 1996.

Zakościele, [w:] Słownik geograficzny Królestwa Polskiego i innych krajów słowiańskich, red. B. Chlebowski et al., t. 14, Warszawa 1895. 